\title{
Correction to: Experimental evaluation of the minimum uncut chip thickness (MUCT) in AISI H13 steel, using the end milling operation
}

\author{
Tatiany Mafra da Silva ${ }^{1} \cdot$ Anselmo Eduardo Diniz ${ }^{1} \cdot$ Reginaldo Teixeira Coelho ${ }^{2}$ \\ Published online: 22 February 2021 \\ (C) Springer-Verlag London Ltd., part of Springer Nature 2021
}

\section{Correction to: The International Journal of Advanced Manufacturing Technology https://doi.org/10.1007/s00170-021-06710-6}

The original article contained a mistake.

The correct bibliographic data for Reference 33 are:

Psyllaki P, Kefalonikas G, Pantazopoulos G, Antoniou S, Sideris J (2003) Microstructure and tribological behaviour of liquid nitrocarburised tool steels. Surf Coat Technol. 162(1):67-78. https://doi.org/10.1016/S0257-8972(02)00566-2

Instead of:

Psyllaki P, Kefalonikas G, Pantazopoulos G, Antoniou S, Sideris J (2002) Microstructure and tribological behaviour of liquid nitrocarburised tool steels. Surf Coat Technol:67-78.

The original article has been corrected.

Publisher's note Springer Nature remains neutral with regard to jurisdictional claims in published maps and institutional affiliations.

The online version of the original article can be found at https://oi.org/ 10.1007/s00170-021-06710-6

Tatiany Mafra da Silva tatiany.mafra@gmail.com

Anselmo Eduardo Diniz anselmo@fem.unicamp.br

Reginaldo Teixeira Coelho rtcoelho@sc.usp.br

1 School of Mechanical Engineering, University of Campinas, Campinas, SP, Brazil

2 São Carlos School of Engineering, University of São Paulo, São Carlos, SP, Brazil 